\title{
Osteoarticular manifestations of pustulosis palmaris et plantaris and of psoriasis: two distinct entities
}

\author{
O Mejjad, A Daragon, J P Louvel, L F Da Silva, E Thomine, P Lauret, X Le Loët
}

\begin{abstract}
Objective-To test the hypothesis that pustulosis palmaris et plantaris and psoriatic arthritis (PsA) are two distinct diseases, and that the associated dermatoses are therefore also distinct diseases.

Methods-We prospectively performed clinical, radiological, biological, and bone scan investigations in 23 outpatients with pustolotic arthritis and 23 outpatients with PsA, matched by gender, age ( \pm one year) and duration of arthritis ( \pm two years).

Results-The anterior chest wall, especially the sternocostoclavicular joints, was more frequently involved in pustulotic arthritis than in PsA, both clinically (82\% $v 43 \% ; p<0.001)$ and radiologically $(47 \%$ $v 17 \%$; $<$ 0.05). Sternocostoclavicular joints generally presented with erosive lesions in PsA, and with large ossifications in pustulotic arthritis. Peripheral joint involvement was mono- or oligoarticular, affecting proximal joints, in pustulotic arthritis $(74 \% v 21 \% ; \mathrm{p}<0.01)$, and polyarticular, involving small distal joints, in PsA $\left(60 \%\right.$ v $\left.0 \% ; \mathrm{p}<10^{-4}\right)$, in which condition it was also more often erosive $(43 \% v 8 \%$; $<0.01)$. The frequency of sacroiliitis and of spine involvement was similar in pustulotic arthritis and PsA. Biology and bone scan did not help distinguish between the two groups.

Conclusions-Pustulotic arthritis and PsA are clinically and radiologically different, therefore pustulosis palmaris et plantaris and psoriasis are most probably distinct dermatological diseases.
\end{abstract}

(Ann Rheum Dis 1996; 55: 177-180)

Pustulosis palmaris et plantaris (PPP) is a chronic pustular dermatosis characterised by sterile pustules on the palms and the soles. ${ }^{1}$ Psoriasis is a well known skin disease with well defined clinical and pathological signs. The relationship between psoriasis and PPP is not clearly defined in the literature: some authors consider PPP as a variant of psoriasis, ${ }^{2-6}$ while others believe it to be a separate entity. ${ }^{178}$ However, there remain grounds for disagreement with this latter hypothesis. ${ }^{2-6}$

We postulated that psoriasis and PPP were two different entities. ${ }^{178}$ Because clinical and pathological cutaneous arguments were not sufficiently convincing for some authors, we undertook a prospective study to compare the osteoarticular manifestations of psoriasis and PPP. If pustulotic arthritis and psoriatic arthritis proved to be clearly different, we could accordingly also consider their associated dermatoses as different.

\section{Patients and methods}

Between 1987 and 1992, in the French administrative region of Haute-Normandie, 23 successive outpatients (15 women, eight men; mean age $45 \cdot 3$ (SD 14.2) years) were identified as having histologically proven PPP according to Pierard and Kint's criteria. ${ }^{1}$ The clinical criteria for selection were: pustules or vesicopustules on the midpalms or thenar eminences of the hands, or both (rare pustules distant from these sites were accepted); nails and acral portions of the fingers and toes spared; absence of psoriasis on any other part of the skin; absence of a family history of psoriasis (in practice, no patient with histologically proven PPP had a relative with psoriasis, therefore we did not have to exclude any patient). Histological criteria comprised a fully developed pustule that was large, intraepidermal in location, unilocular; various stages of pustule formation could be observed (spongiosis appearing in the epidermis above the top of a dermal papilla, giving a vesicle filled with fluid and mononuclear cells; malpighian roof disrupted, leading to a massive invasion of the cavity by polymorphonuclear leucocytes that penetrate into the intracellular spaces of the vesicle wall, where spongiform pustules were seen). All the subjects had or had had osteoarticular manifestations characterised by peripheral arthralgia or arthritis, spine or sacroiliac joint pain, and anterior chest wall pain or swelling. Five patients with pustules on the palms and soles associated with psoriasis on other parts of their skin were not included because histological examination of a pustule specimen revealed psoriasis and not PPP; thus no patient included in the PPP group was suffering from psoriasis.

Twenty three PsA outpatients in an active phase of their rheumatic disease matched by gender, age ( \pm one year), age at onset of arthritis, and duration of arthritis at first examination ( \pm two years), were also recruited to the study (15 women, eight men; mean age 45.6 (SD 13.1) years). The clinical criteria for selection were: scalp, sacral region, extensor surfaces of the limbs, nails, intertriginous areas mainly affected; entire skin may be affected; lesions sharply demarcated and covered with 
Table 1 Demographic characteristics of patients with pustulosis palmaris et plantaris (PPP) or psoriasis

\begin{tabular}{lcc}
\hline & $P P P$ & Psoriasis \\
\hline Age (years) & $45 \cdot 3(14 \cdot 2)$ & $45 \cdot 6(13 \cdot 1)$ \\
$\begin{array}{l}\text { Age at onset of arthritis (years) } \\
\begin{array}{l}\text { Duration of arthritis at first } \\
\text { examination (years) }\end{array}\end{array}$ & $76.9(14 \cdot 4)$ & $38.0(13 \cdot 8)$ \\
\hline
\end{tabular}

Values are mean (SD).

No significant differences between groups.

layers of fine scales, removal of which by gentle scraping usually revealing fine bleeding points. Histological criteria comprised: elongation of the rete ridges with thickening in their lower portion; elongation and oedema of the papillae; thinning of the suprapapillary portions of the stratum malpighii, with the occasional presence of a very small spongiform pustule; parakeratosis and the presence of Munro microabscesses. Psoriasis was recognised clinically by an experienced dermatologist (P L), and histologically in case of doubt. ${ }^{9}$

The 46 patients underwent the following investigations:

(1) Physical examination by the same rheumatologist. All osteoarticular manifestations, past or present, with spontaneous pain or pain on pressure, were considered. Spine involvement was clinically assessed by pain (past or present) and by the Shober's test.

(2) Technetium-99m pyrophosphate bone scan, radiography of hands, feet, pelvis, dorsolumbar spine, and manubriosternal joint, and computed tomography of sternoclavicular joints. Additional radiographs were taken in cases of bone scan abnormality and osteoarticular manifestations in other sites. Radiographs and computed tomography data of the patients were read blindly and separately by two rheumatologists and two radiologists well trained in osteoarticular radiology. ${ }^{10}$ In the

Table 2 Dermatological findings

\begin{tabular}{|c|c|c|c|c|}
\hline \multirow[t]{2}{*}{ Patient } & \multicolumn{2}{|l|}{$P P P$} & \multicolumn{2}{|l|}{ Psoriasis } \\
\hline & $\begin{array}{l}\text { Clinical distribution } \\
\text { of pustules }\end{array}$ & $\begin{array}{l}\text { Histological } \\
\text { examination }\end{array}$ & $\begin{array}{l}\text { Clinical distribution of } \\
\text { psoriasis }\end{array}$ & $\begin{array}{l}\text { Histological } \\
\text { examination }\end{array}$ \\
\hline 1 & Palms and soles & PPP & $\begin{array}{l}\text { Face, scalp, trunk, elbows, } \\
\text { knees, sacral region }\end{array}$ & \\
\hline 2 & Palms and soles & PPP & $75 \%$ of the entire skin & Psoriasis \\
\hline 3 & Palms and soles & PPP & Elbows, scalp, legs, trunk & \\
\hline 4 & Palms and soles & PPP & Knees elbows, scalp, legs & \\
\hline 5 & Palms and soles & PPP & Elbows, knees, nails & \\
\hline 6 & Soles & PPP & Knees, scalp, nails & \\
\hline $\begin{array}{l}7 \\
8\end{array}$ & Palms and soles & $\begin{array}{l}\text { PPP } \\
\text { PPP }\end{array}$ & Elbows, knees, thighs & Psoriasis \\
\hline 9 & $\begin{array}{l}\text { Paims and soles } \\
\text { Palms and soles }\end{array}$ & $\begin{array}{l}\text { PPP } \\
\text { PPP }\end{array}$ & $\begin{array}{l}\text { Thighs } \\
\text { Elbows, scalp, palms and }\end{array}$ & T Soilasis \\
\hline 10 & Palms and soles & PPP & $\begin{array}{l}\text { soles, nains } \\
\text { Elbows, knees, sacral region }\end{array}$ & \\
\hline 11 & Soles & PPP & Arms, forearms, scalp, legs & \\
\hline 12 & Palms and soles & PPP & Scalp, legs & \\
\hline 13 & Palms and soles & PPP & $\begin{array}{l}\text { Elbows, scalp, palms and } \\
\text { soles }\end{array}$ & Psoriasis \\
\hline 14 & Palms and soles & PPP & $\begin{array}{l}\text { Elbows, knees, scalp, sacral } \\
\text { region, thighs }\end{array}$ & \\
\hline 15 & Palms & PPP & Elbows, knees, scalp & \\
\hline $\begin{array}{l}16 \\
17\end{array}$ & $\begin{array}{l}\text { Palms } \\
\text { Palms }\end{array}$ & $\begin{array}{l}\text { PPP } \\
\text { PPP }\end{array}$ & $\begin{array}{l}\text { Elbows, knees, sacral region } \\
\text { Scalp, sacral region }\end{array}$ & \\
\hline 18 & Palms and soles & PPP & Scalp, knees & Psoriasis \\
\hline 19 & Palms and soles & PPP & $\begin{array}{l}\text { Scalp, toes, nails, elbows, } \\
\text { knees }\end{array}$ & \\
\hline 20 & Palms & PPP & $\begin{array}{l}\text { Scalp, elbows, knees, sacral } \\
\text { region, trunk }\end{array}$ & \\
\hline 21 & Soles & PPP & $\begin{array}{l}\text { Elbows, knees, sacral region, } \\
\text { scalp }\end{array}$ & \\
\hline $\begin{array}{l}22 \\
23\end{array}$ & $\begin{array}{l}\text { Palms and soles } \\
\text { Palms and soles }\end{array}$ & $\begin{array}{l}\text { PPP } \\
\text { PPP }\end{array}$ & $\begin{array}{l}\text { Legs, scalp } \\
\text { Elbows, forearms, fingers, } \\
\text { nails, scalp }\end{array}$ & Psoriasis \\
\hline
\end{tabular}

^All PPP = histologically proven pustulosis palmaris et plantaris; all psoriasis $=$ histologically proven psoriasis. event of disagreement between readers, a consensus was obtained by 'collegial' reading, according to Sonosaki's classification for sternoclavicular joints whenever possible. ${ }^{11} 12$ Radiological interpretation was descriptive only when Sonosaki's classification was not adequate. Dilsen's classification was used for manubriosternal joints ${ }^{13}$ and that of Dale for sacroiliac joints. ${ }^{14}$

(3) Laboratory investigations: full blood count, erythrocyte sedimentation rate (ESR), serum alkaline phosphatases, latex agglutination test, serum IgA by laser nephelometry, HLA-A, -B, -C and -DR typing, and bacteriological examination of pustules, when possible.

Statistical analysis was by the $\chi^{2}$ test to compare the two groups.

\section{Results}

Table 1 shows the demographic characteristics of PPP and psoriasis patients; table 2 lists the dermatological findings.

Skeletal and skin symptoms appeared simultaneously ( \pm 6 months) in nine of the 23 PPP patients (39\%), and in four of the 23 psoriasis patients $(17 \%)$ (not statistically significant). Skin and skeletal flares occurred in eight PPP patients $(35 \%)$ and two patients with psoriasis $(8.7 \%)(p<0.05)$

Two PPP patients had relatives with an unclassified rheumatism without skin disease; no familial case of PPP, psoriasis, or pustulotic arthritis was found. Nine of the 23 PsA patients $(39 \%)$ had relatives with psoriasis and two patients had relatives with rheumatism (unclassified rheumatism in the first case, and psoriatic arthritis in the second).

Table 3 shows the clinical findings. The two groups were not different for spine and sacroiliac joint manifestations, but they differed in anterior chest wall involvement $(p<0.001)$, especially that of the sternoclavicular joint, which was more frequently implicated in the PPP group $(p<0.05)$. The frequency of peripheral joint manifestations did not differ between the groups, but the nature of this involvement was different: mono- or oligoarticular (17/23), but never polyarticular, in the case of PPP, but predominantly polyarthritis $(14 / 23)$ in the case of psoriasis. The main sites were the shoulders $(64 \%)$ for PPP and small distal joints (58\%) for psoriasis. Enthesitis at a distance from joints was noted in four PPP patients, involving either heel, iliac crest, ischium, or trochanter, and in 11 psoriatic patients $(p<0.05)$.

Table 3 also shows the radiological findings. The anterior chest wall was more frequently involved during pustulotic arthritis $(p<0.05)$. In spite of more frequent lesions of the sternoclavicular joints in the PPP group, the difference was not statistically significant. However, the three psoriatic patients with sternoclavicular arthritis presented with erosive lesions (fig 1), whereas the eight PPP cases had associated erosive lesions and ossifications (fig 2). Spine and sacroiliac manifestations were not different between the two groups: 
Table 3 Clinical and radiological findings and comparison between patients with pustulosis palmaris et plantaris (PPP) or psoriasis

\begin{tabular}{|c|c|c|c|c|c|c|}
\hline & \multicolumn{3}{|c|}{ Clinical findings } & \multicolumn{3}{|c|}{ Radiological findings } \\
\hline & $\begin{array}{l}P P P \\
(n=23)\end{array}$ & $\begin{array}{l}\text { Psoriasis } \\
(n=23)\end{array}$ & $p$ & $\begin{array}{l}P P P \\
(n=23)\end{array}$ & $\begin{array}{c}\text { Psoriasis } \\
(n=23)\end{array}$ & $p$ \\
\hline $\begin{array}{l}\text { Anterior chest wall } \\
\text { Sternoclavicular } \\
\text { Manubriosternal } \\
\text { Sternocostal }\end{array}$ & $\begin{array}{r}19(82 \cdot 6) \\
14(60 \cdot 8) \\
5(21 \cdot 7) \\
7(30 \cdot 4)\end{array}$ & $\begin{array}{c}10(43 \cdot 5) \\
7(30 \cdot 4) \\
2(8 \cdot 7) \\
4(17 \cdot 4)\end{array}$ & $\begin{array}{l}<0.001 \\
<0.05 \\
\text { NS } \\
\text { NS }\end{array}$ & $\begin{array}{r}11(47 \cdot 8) \\
8(34 \cdot 8) \\
3(13 \cdot 0)\end{array}$ & $\begin{array}{l}4(17 \cdot 4) \\
3(13 \cdot 0) \\
1(4 \cdot 3)\end{array}$ & $\begin{array}{l}<0.05 \\
\text { NS } \\
\text { NS }\end{array}$ \\
\hline $\begin{array}{l}\text { Spine } \\
\text { Sacroiliac joints }\end{array}$ & $\begin{array}{r}19(82 \cdot 6) \\
8(34 \cdot 8) \\
17(73 \cdot 9)\end{array}$ & $\begin{array}{r}15(65 \cdot 2) \\
7(30 \cdot 4) \\
19(82 \cdot 6)\end{array}$ & $\begin{array}{l}\text { NS } \\
\text { NS }\end{array}$ & $\begin{array}{l}7(30 \cdot 4) \\
8(34 \cdot 8) \\
2(8 \cdot 7)\end{array}$ & $\begin{array}{r}8(34 \cdot 8) \\
4(17 \cdot 4) \\
10(43 \cdot 5)\end{array}$ & $\begin{array}{l}\text { NS } \\
\text { NS } \\
<0 \cdot 01\end{array}$ \\
\hline $\begin{array}{l}\text { Peripheral joints } \\
\text { Arthralgia } \\
\text { Arthritis } \\
\text { Mono/oligoarticular } \\
\text { Polyarticular }\end{array}$ & $\begin{array}{r}17(73 \cdot 9) \\
9 \\
8 \\
17 \\
0\end{array}$ & $\begin{array}{r}19(82 \cdot 6) \\
4 \\
15 \\
5 \\
14\end{array}$ & $\begin{array}{l}<0.02 \\
<0.001 \\
<10^{-5}\end{array}$ & & & \\
\hline
\end{tabular}

Values are number $(\%)$

NS $=$ not significant.

sacroiliitis, syndesmophytes, and multiple osteophytes were found with the same frequency. Erosive arthritis of the peripheral joints was more frequent in the psoriasis group $(p<\theta .01)$. We noted only two cases of erosive arthritis in the PPP group, involving the hip in the first case, and radioulnar and second and

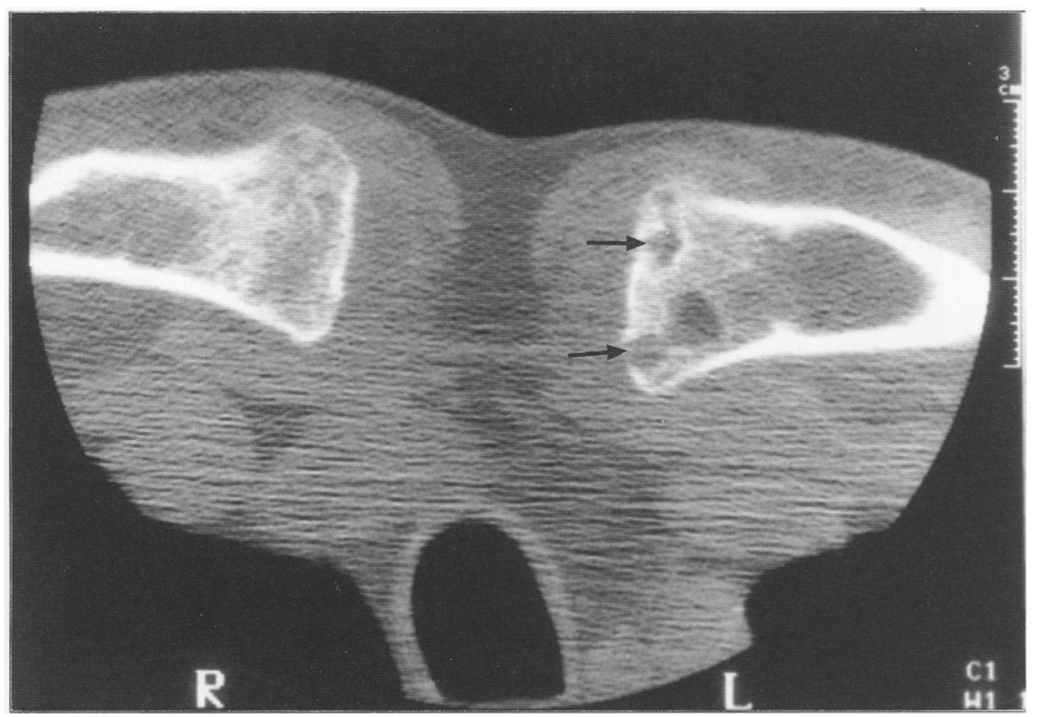

Figure 1 Computed tomography scan of sternocostoclavicular joints in a patient with psoriatic arthritis, demonstrating only erosive lesions, without ossification.

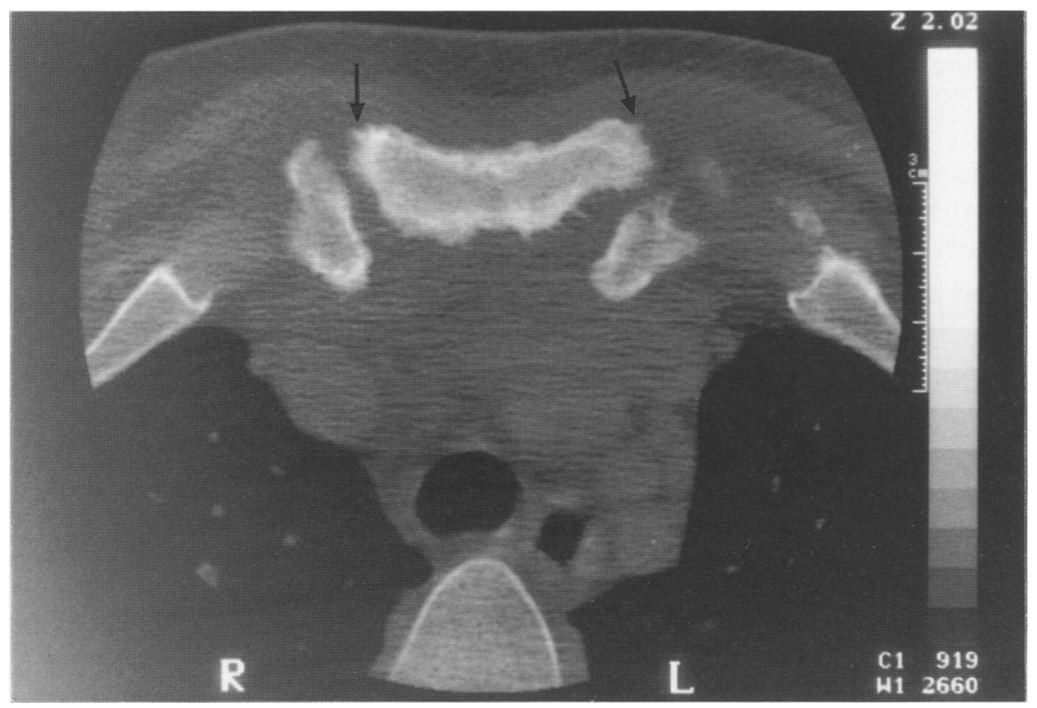

Figure 2 Computed tomography scan of sternocostoclavicular joints in a patient with pustulotic arthritis, demonstrating large ossifications.
Table 4 Bone scan findings and comparison between patients with pustulosis palmaris et plantaris (PPP) or psoriasis

\begin{tabular}{lcrl}
\hline & $\begin{array}{c}P P P \\
(n=23)\end{array}$ & $\begin{array}{c}\text { Psoriasis } \\
(n=23)\end{array}$ & $p$ \\
\hline Anterior chest wall & $12(52 \cdot 2)$ & $7(30 \cdot 4)$ & NS \\
Sternoclavicular joints & $11(47 \cdot 8)$ & $4(17 \cdot 4)$ & $<0 \cdot 05$ \\
Manubriosternal joint & $1(4 \cdot 3)$ & $3(13.0)$ & NS \\
Spine & $4(17 \cdot 4)$ & $7(30.4)$ & NS \\
Sacroiliac joints & $7(30 \cdot 4)$ & $7(30.4)$ & NS \\
Peripheral joints & $7(30 \cdot 4)$ & $12(52 \cdot 2)$ & NS \\
\hline Values are number (\%). & & &
\end{tabular}

third metacarpophalangeal (MCP) joints in the second case.

Chronic recurrent multifocal osteitis was observed in three patients with PPP: one involved the femur, another the clavicle, and one patient had tibial, femoral and pelvic localisations. In the psoriasis group, we observed only one patient with vertebral and clavicular localisations.

Table 4 shows the bone scan findings. No statistical difference was observed between the two groups, except that sternoclavicular joint involvement was more frequent in pustulotic arthritis $(\mathrm{p}<0.05)$.

There was no statistical difference between the groups in the frequency of increased ESR $(>20 \mathrm{~mm} / 1 \mathrm{st} \mathrm{h}$ ), increased leucocyte count $\left(>10^{9} / 1\right)$, or serum alkaline phosphatase concentrations. Latex agglutination test was negative in all cases. Serum IgA titre was more frequently increased in the psoriasis group $(78.9 \%$ v 40\%; p < 0.001). HLA-A, -B, -C, -DR typing was unremarkable except for the HLA-B27 antigen, which was found in 9.5\% of PPP patients-a rate not different from that observed in a control population in Normandy ${ }^{15}$ - and in $27.3 \%$ of patients with psoriasis.

Spondylarthropathy testing revealed nine (39\%) PPP patients and $23(100 \%)$ psoriasis patients to be positive according to the criteria of the European Spondylarthropathy Study Group (ESSG). ${ }^{16}$

\section{Discussion}

Many authors consider psoriasis and PPP to be the same disease, ${ }^{2-6}$ while others view them as different dermatological disorders; $;^{18}$ debate on the clinical and anatomopathological features of PPP and its relationship to psoriasis continues. ${ }^{17}$ We postulated that PPP and psoriasis were separate entities, ${ }^{178}$ and we undertook the present prospective study to compare the frequency and the type of osteoarticular manifestations of these two dermatological diseases. If the findings for pustulotic arthritis and psoriatic arthritis were clearly different, we could consider them as separate entities.

We investigated two different groups of patients with well-defined dermatological criteria at inclusion (table 2) and demonstrated that, statistically, the two types of rheumatism were different in several manifestations, and often in the kind of joint involvement. Thus we 
conclude that PPP and psoriasis are probably two distinct dermatological diseases.

The anterior chest wall and, especially, the sternoclavicular joints were more frequently implicated during PPP. The frequency of clinical anterior chest wall involvement in PPP as reported in the literature varies from 60 to $100 \% ;^{11} 121819$ our findings confirmed this high incidence.

While the frequency of peripheral joint signs and symptoms was about the same in the two groups, the nature of this involvement was different: mono- or oligoarticular for PPP, but polyarticular for psoriasis. This difference was confirmed by radiological findings. In spite of a non-significant difference for sternoclavicular involvement (probably attributable to the small number of the patients included in this study), the type of lesions in general differed between the conditions: erosive arthritis was found in psoriasis (fig 1), while there was an association of erosive lesions and ossifications in PPP (fig 2); this was described previously by Sonosaki et al. ${ }^{11}{ }^{12}$ Erosive arthritis of the peripheral joints is rare in PPP; we found two such cases, involving the hip in the first, and the wrist and MCP joints in the second. Only 11 other cases have previously been reported in the literature.$^{20-23}$ Erosive arthritis of the peripheral joints is a more common feature in psoriatic arthritis, ${ }^{24}$ as was confirmed in our study.

Biological findings did not differ between the two groups and were thus not helpful in distinguishing between the two entities. There was no link with the HLA-B27 antigen in the PPP group, which was in agreement with other results. $^{12} 18$ The frequency of B27 antigen in the psoriasis group $(27 \cdot 3 \%)$ was similar to that reported from other studies. ${ }^{25} 26$

We tested all patients for the ESSG criteria, and $39 \%$ of the PPP patients were positive. It seems valid to consider anterior chest wall involvement as an enthesitis, because of the large number of ligaments and tendons in the sternocostoclavicular and manubriosternal regions. When we also considered PPP as a criterion, in common with psoriasis, 20 PPP patients $(87 \%)$ became positive according to the ESSG criteria. In agreement with Sonozaki et al, we believe that pustulotic arthritis could be included in the spondylarthropathy group. ${ }^{12}$

In conclusion, even if the osteoarticular manifestations associated with PPP and with psoriasis are considered to belong to the spondylarthropathy group of diseases, they have been shown to be different, as we initially postulated. In light of these data, we believe that PPP and psoriasis are separate dermatological entities. However, an epidemiological study is required, to determine how many patients have 'pure' PPP, how many have 'pure' psoriatic arthropathy, and how many have an 'overlap'.

The authors thank Mrs Foster for reviewing this paper

1 Pierard J, Kint A. La pustulose palmo-plantaire chronique et récidivante. Ann Derm Venereol (Stockh) 1978; 105: et récidiv.

2 Barber $\mathrm{H}$ W. Acrodermatitis continua vel perstans. $\mathrm{Br} \mathscr{f}$ Dermatol 1930; 42: 500-18.

3 Burks J W, Montgomery H. Histopathologic study of psoriasis. Arch Dermatol Syphilol 1943; 48: 479-93.

4 Enfors W, Molin L. Pustulosis palmaris et plantaris. A follow-up study of a ten-year material. Acta Derm Venereol (Stockh) 1971; 51: 289-94.

5 Ingram J T. Acrodermatitis perstans and its relation to psoriasis. Br F Dermatol 1930; 42: 489-99.

6 Sachs W, Scannone F. So-called 'pustular psoriasis'. $\mathcal{f}$ Invest Dermatol 1945; 6: 341-54.

7 Ward J M, Barnes R M R. HLA antigens in persisten palmoplantar pustulosis and its relationship to psoriasis. Brf Dermatol 1978; 99: 477-83.

8 Hellgren L, Mobacken H. Pustulosis palmaris et plantaris Prevalence, clinical observations and prognosis. Acto Derm Venereol 1971; 51: 284-8.

9 Lever W F, Schaumburg-Lever G. Psoriasis. In: Lever W F, Schaumburg-Lever G, eds. Histopathology of the skin. Philadelphia: J B Lippincott Company, 1990; 156-64.

10 Lucet L, Le Loët X, Louvel J P, et al. Computed tomography of normal sternoclavicular joint. Skeletal Radiol 1995. In press.

11 Sonozaki $\mathrm{H}$, Kawashima M, Hongo O, et al. Incidence of arthro-osteitis in patients with pustulosis palmaris et arthro-osteitis in patients with pustulosis
plantaris. Ann Rheum Dis 1981; 40: 554-7.

12 Sonozaki $\mathrm{H}$, Mitsui $\mathrm{H}$, Miyanaga $\mathrm{Y}$, et al. Clinical features of 53 cases with pustulotic arthro-osteitis. Ann Rheum Dis 1981; 40: 547-53.

13 Dilsen N, McEwen C, Poppel M, Gersh W J, DiTata D Carmel P. A comparative roentgenologic study of rheumatoid arthritis and rheumatoid (ankylosing) spondylitis. Arthritis Rheum 1962; 5: 341-68.

14 Dale K, Vinje O. Radiography of the spine and sacro-iliac joints in ankylosing spondylitis and psoriasis. Acta Radiol Diagnosis 1985; 26: 145-59.

15 Thorel J B, Cavelier B, Bonneau J C, Simonin J L, Ropartz C, Deshayes P. Etude d'une population porteuse dé l'antigene HLA B27 comparee à celle d'une population
témoin non B27 à la recherche de la spondylarthrite témoin non B27 à la recherche de la spo
ankylosante. Rev Rhum 1978; 45: 275-82.

16 Amor B, Dougados M, Listrat V, et al. Evaluation de critères des spondylarthropathies d'Amor et de l'European Spondylarthropathy Study Group (ESSG) Une étude transversale de 2228 patients. Ann Med Int 1991 ; 142: 85-9.

17 Thormann J, Heilesen B. Recalcitrant pustular eruptions of the extremities. F Cutan Pathol 1975; 2: 19-24.

18 Chamot A M, Benhamou C I, Kahn M F, Beraneck L Kaplan G, Prost A. Le syndrome acné pustulose hyperostose ostéite (SAPHO). Résultat d'une enquête nationale. 85 observations. Rev Rhum 1987; 54: 187-96.

19 Le Loët X, Bonnet B, Thomine E, et al. Manifestation ostéo-articulaires de la pustulose palmo-plantaire. Etud prospective de 15 cas. Presse Med 1991; 20: 1307-11.

20 Huaux J P, Malghem J, Rombouts J J, et al. Ostéomyélite récidivante multifocale chronique de l'enfant et pustulose palmo-plantaire. A propos d'un nouveau cas. Rev Rhum 1987; 54: 403-5.

21 Ralston S H, Scott P D R, Sturrock R D. An unusual case of pustulotic arthro-osteitis affecting the leg, and erosive polyarthritis. Ann Rheum Dis 1990; 49: 643-5.

22 Ziza J M, Frances-Michel C, Tabah I, Bletry O, Godeau P. Carpite bilatérale au cours d'une pustulose palmoCarpite bilatérale au cours d'une pus

23 Le Goff P, Baron D, Le Henaff C, Ehrhart A, Leroy J P. Arthrites destructrices périphériques au cours de la pustulose palmo-plantaire. A propos de troi observations. Rev Rhum 1992; 59: 443-8.

24 Jones S M, Armas J B, Cohen M G, Lovell C R, Evison G McHugh N J. Psoriatic arthritis: outcome of disease subsets and relationship of joint disease to nail and skin disease. Br F Rheumatol 1994; 33: 834-9.

25 Armstrong R D, Panayi G S, Welsh K I. Histocompatibility antigens in psoriasis, psoriatic arthropathy, and ankylosing spondylitis. Ann Rheum Dis 1983; 42: 142-6.

26 Gladman D D, Anhorn K A B, Schachter R K, Mervart H. HLA antigens in psoriatic arthritis. $\mathcal{f}$ Rheumatol 1986; 13: 586-92. 